\title{
Augmented Renal Clearance in a Case of Sepsis Leading to Vancomycin Failure Despite Increasing Dose As per the Estimated Glomerular Filtration Rate
}

\author{
Rama Kanth Pata ${ }^{1}$, Chhabilal Bastola ${ }^{2}$, Nway Nway ${ }^{2}$, Meet J. Patel ${ }^{2}$, Samaj Adhikari ${ }^{2}$ \\ 1. Pulmonary Medicine, Interfaith Medical Center, Brooklyn, USA 2. Internal Medicine, Interfaith Medical Center, \\ Brooklyn, USA
}

Corresponding author: Rama Kanth Pata, cookybrey1@gmail.com

\begin{abstract}
Augmented renal clearance (ARC) is a unique clinical scenario observed in critically ill patients. We present a case of a 30-year-old male with sepsis secondary to methicillin-resistant Staphylococcus aureus (MRSA) bacteremia treated with vancomycin. ARC was observed in the patient with a maximum estimated glomerular filtration rate (eGFR) of $161.9 \mathrm{ml} / \mathrm{min} / 1.73 \mathrm{~m}^{2}$, and therapeutic drug monitoring was used to adjust the vancomycin dosage. Despite the maximal recommended dose of vancomycin, the therapeutic vancomycin level was not achieved, leading to treatment failure and subsequent mortality. Our case report suggests the necessity of other strategies, such as early dose adjustment of vancomycin based on vancomycin clearance and continuous vancomycin infusion, not merely conventional adjustment based on eGFR and vancomycin levels.
\end{abstract}

Review began 03/06/2021 Review ended 03/24/2021 Published 03/30/2021

\section{๑) Copyright 2021}

Pata et al. This is an open access article distributed under the terms of the Creative Commons Attribution License CC-BY 4.0., which permits unrestricted use, distribution, and reproduction in any medium, provided the original author and source are credited.
Categories: Internal Medicine, Infectious Disease, Pulmonology

Keywords: vancomycin, augmented renal clearance, arc, sepsis, mrsa

\section{Introduction}

Dosing of drugs in intensive care has a huge impact on outcomes. Frequently, dosing is adjusted based on pharmacokinetics, which is dependent on many factors and not just limited to co-morbidities and rapidly changing hemodynamics. Active vigilance should be exercised in liaison with a dedicated pharmacist; more importantly, for those drugs with a narrow therapeutic window and those medications whose efficacy depends on the therapeutic level. In an intensive care setting, anticoagulation and antibiotics require therapeutic drug monitoring. Vancomycin-induced renal toxicity requiring hemofiltration has been reported in the intensive care setting [1-2]. Most commonly, antibiotics are adjusted based on the degree of reduction of eGFR from baseline to prevent toxicity. On the contrary, an increase in eGFR would result in therapeutic failure. Augmented renal clearance (ARC) is a unique phenomenon encountered in critically ill patients, resulting in the enhanced elimination of solutes, higher than expected for age, clinical co-morbidity, or gender. The phenomenon of ARC was documented in the 1970s in burn patients who required higher doses of aminoglycosides and was attributed to renal hyperfiltration [3]. ARC is considered when creatinine clearance exceeds $130 \mathrm{ml} / \mathrm{min} / 1.73 \mathrm{~m}^{2}$ [4-5]. ARC has been reported among severely septic patients, traumatic brain injury, and young and healthy individuals who have undergone surgery or multiple trauma [6-7]. Many predictive scoring systems and tools are used to predict ARC. A failure to do early projection can lead to antibiotic failure resulting in mortality. We present a case of a critically ill patient with ARC secondary to methicillin-resistant Staphylococcus aureus (MRSA) sepsis, resulting in vancomycin failure and mortality.

\section{Case Presentation}

A 30-year-old male (weight $72.5 \mathrm{~kg}$ and height: $6 \mathrm{ft}$ 3-inch, body mass index (BMI) of $20.0 \mathrm{~kg} / \mathrm{m}^{2}$ ) with a past medical history of intravenous drug use and schizophrenia presented to the emergency department with progressive shortness of breath, fever, and chills for three days. At presentation, his temperature was $102^{\circ} \mathrm{F}$, heart rate of $\sim 120$ /min, respiratory rate $\sim 30-35$ breaths/min, and oxygen saturation of $93 \%$ - $94 \%$ on room air. Physical examination revealed bilateral crepitation on the bases of the lungs. Complete blood count was significant for neutrophilia, and a preliminary diagnosis of sepsis was made. Table 1 shows the laboratory workup on admission. 


\section{Cureus}

\begin{tabular}{|c|c|c|c|c|c|}
\hline Tests & Results & Normal values & Tests & Results & Normal values \\
\hline Lactic acid & $2.8 \mathrm{mmol} / \mathrm{l}$ & $0.5-1.9 \mathrm{mmol} / \mathrm{l}$ & Calcium & $8.6 \mathrm{mg} / \mathrm{dl}$ & $8.4-10.2 \mathrm{mg} / \mathrm{dl}$ \\
\hline Sodium & 134 mmol/l & $136-145 \mathrm{mmol} / \mathrm{l}$ & Phosphorus & $4.8 \mathrm{mg} / \mathrm{dl}$ & $2.3-4.7 \mathrm{mg} / \mathrm{dl}$ \\
\hline Potassium & $3.4 \mathrm{mmol} / \mathrm{l}$ & $3.5-5.1 \mathrm{mmol} / \mathrm{l}$ & Magnesium & $1.7 \mathrm{mg} / \mathrm{dl}$ & $1.6-2.6 \mathrm{mg} / \mathrm{dl}$ \\
\hline $\mathrm{HCO}_{3}-$ & $26 \mathrm{mEq} / \mathrm{L}$ & $22-29 \mathrm{mEq} / \mathrm{L}$ & Total bilirubin & 1.8 & $0.2-1.2 \mathrm{mg} / \mathrm{dl}$ \\
\hline Anion gap & 10 & $8-16$ & AST & $55 \mathrm{U} / \mathrm{L}$ & 5-34 U/L \\
\hline BUN & $12.9 \mathrm{mg} / \mathrm{dl}$ & $8.4-25.7 \mathrm{mg} / \mathrm{dl}$ & ALT & $64 \mathrm{U} / \mathrm{L}$ & 10-55 U/L \\
\hline Creatinine & 0.96 mg/dl & $0.72-1.25 \mathrm{mg} / \mathrm{dl}$ & ALP & $42 \mathrm{U} / \mathrm{L}$ & 40-150 U/L \\
\hline Glucose & $152 \mathrm{mg} / \mathrm{dl}$ & $70-105 \mathrm{mg} / \mathrm{dl}$ & Total protein & $5.6 \mathrm{gm} / \mathrm{dl}$ & $6.0-8.3 \mathrm{gm} / \mathrm{dl}$ \\
\hline
\end{tabular}

\section{TABLE 1: Laboratory workup on admission}

$\mathrm{Hco3}^{-}$: serum bicarbonate; BUN: blood urea nitrogen; AST: aspartate transaminase; ALT: alanine transaminase; ALP: alkaline phosphatase; mg/dl: milligram per deciliter; mmol/l: millimoles per liter; U/L: unit per liter

CT chest (Figure 1) revealed innumerable different-sized irregular-shaped patchy and nodular densities in bilateral lungs (red arrows), some of them with central cavitation. Based on clinical manifestations and radiologic imaging, sepsis secondary to pneumonia was diagnosed.

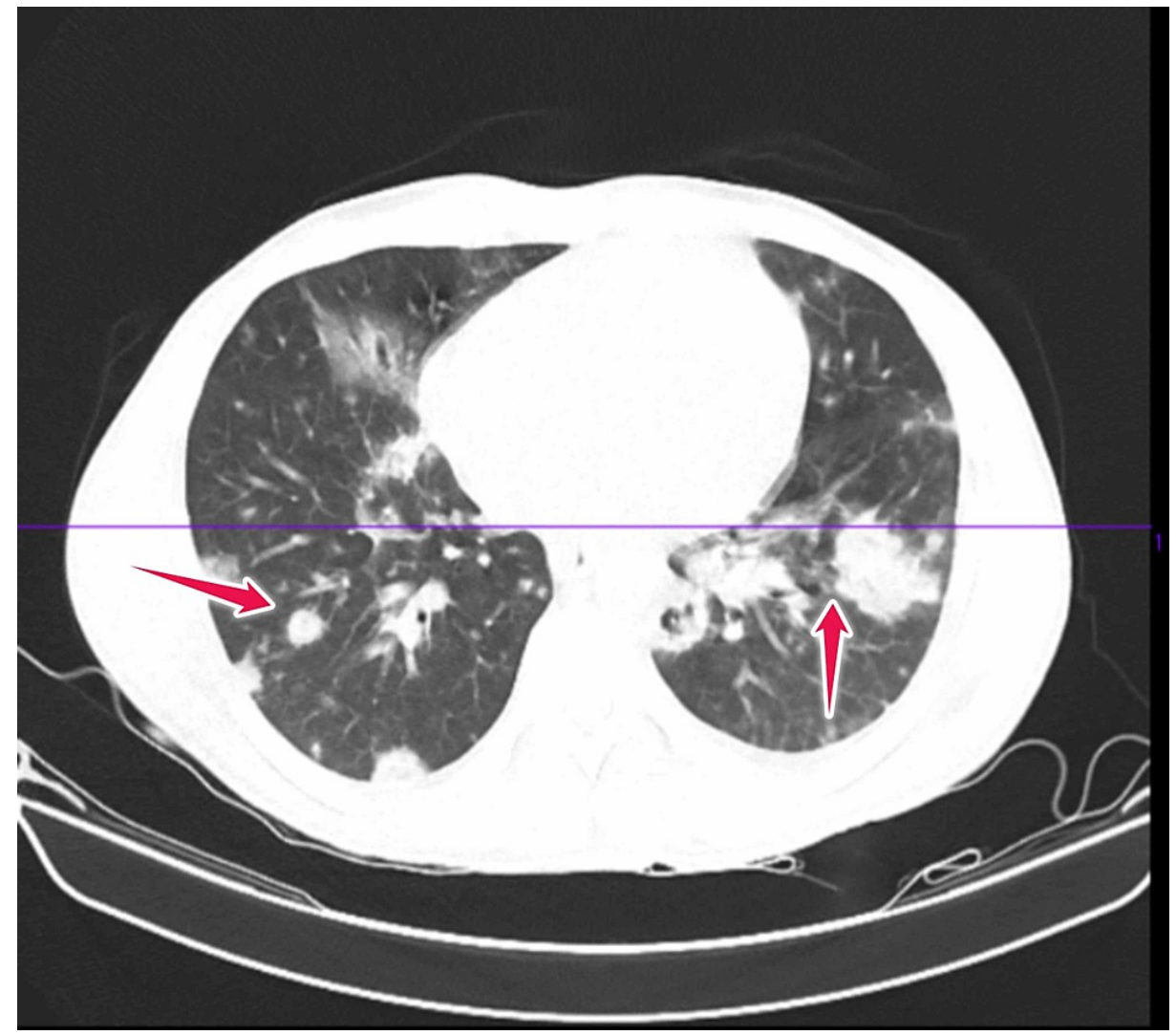

FIGURE 1: CT scan of chest done at the time of admission

CT: computed tomography

In view of intravenous drug use, there was a high index of suspicion of MRSA sepsis. The patient was empirically treated with meropenem 1 gm every eight hourly and vancomycin 1 gm every 12 hourly to have synergistic action against MRSA sepsis. 


\section{Cureus}

Bronchoscopy was done, and bronchoalveolar lavage (BAL) revealed MRSA. Meropenem was discontinued on Day 4 when MRSA was isolated. Later on, vancomycin was continued for MRSA sepsis. The patient required endotracheal intubation owing to hypoxemic respiratory failure.

Vancomycin was started on Day 1 with 1 gram every 12 hours $(27.7 \mathrm{mg} / \mathrm{kg})$. After three initial doses, the vancomycin trough was $5.8 \mathrm{mg} / \mathrm{dl}$. The critical care pharmacy was consulted, and vancomycin dosing was changed to $1 \mathrm{gm}$ every eight hours $(42.8 \mathrm{mg} / \mathrm{kg}$ ). On Day 4 , the vancomycin level was $9.6 \mathrm{mg} / \mathrm{dl}$, so the dose of vancomycin was increased further to 1 gram every six hours $(55.5 \mathrm{mg} / \mathrm{kg})$. On Days 5 and 6, he received a total of $4.25 \mathrm{gm}$ per day $(\sim 59 \mathrm{mg} / \mathrm{kg})$ of vancomycin. Despite these doses, the patient was not able to reach the therapeutic vancomycin levels. Consultation with the infectious disease team was done and the antibiotic was switched to ceftaroline and daptomycin. Linezolid was not considered in view of possible bone marrow suppression [8].

Table 2 shows the vancomycin dose adjustment based on eGFR while Figure 2 shows the estimated glomerular filtration rate (eGFR) trend based on the Modification of Diet in Renal Disease (MDRD) study equation.

\begin{tabular}{|l|l|}
\hline eGFR & Vancomycin dose \\
\hline $96.5 \mathrm{ml} / \mathrm{min} / 1.73 \mathrm{~m} 2$ & $1 \mathrm{gm} \mathrm{Q12} \mathrm{HR}(27.7 \mathrm{mg} / \mathrm{kg})$ \\
$101.4 \mathrm{ml} / \mathrm{min} / 1.73 \mathrm{~m} 2$ & $1 \mathrm{gm} \mathrm{Q8} \mathrm{HR}(42.8 \mathrm{mg} / \mathrm{kg})$ \\
$134.08 \mathrm{ml} / \mathrm{min} / 1.73 \mathrm{~m} 2$ & $1 \mathrm{gm} \mathrm{Q8HR}(42.8 \mathrm{mg} / \mathrm{kg})$ \\
$150.63 \mathrm{ml} / \mathrm{min} / 1.73 \mathrm{~m} 2$ & $1 \mathrm{gm} \mathrm{Q6HR}(55.5 \mathrm{mg} / \mathrm{kg})$. \\
$161.9 \mathrm{ml} / \mathrm{min} / 1.73 \mathrm{~m} 2$ & $4.25 \mathrm{gm}$ day in $4 \mathrm{divided}$ doses $(59 \mathrm{mg} / \mathrm{kg})$ \\
\hline
\end{tabular}

\section{TABLE 2: Vancomycin dose adjustment based on eGFR}

eGFR: estimated glomerular filtration rate; $\mathrm{ml} / \mathrm{min}$ : milliliter per minute; $\mathrm{m}^{2}:$ meter square; mg/kg: milligram per kilogram; gm: gram; q12 HR: every 12 hourly; q8 HR: every eight hourly; q6 HR: every six hourly; HR: hour 


\section{Cureus}

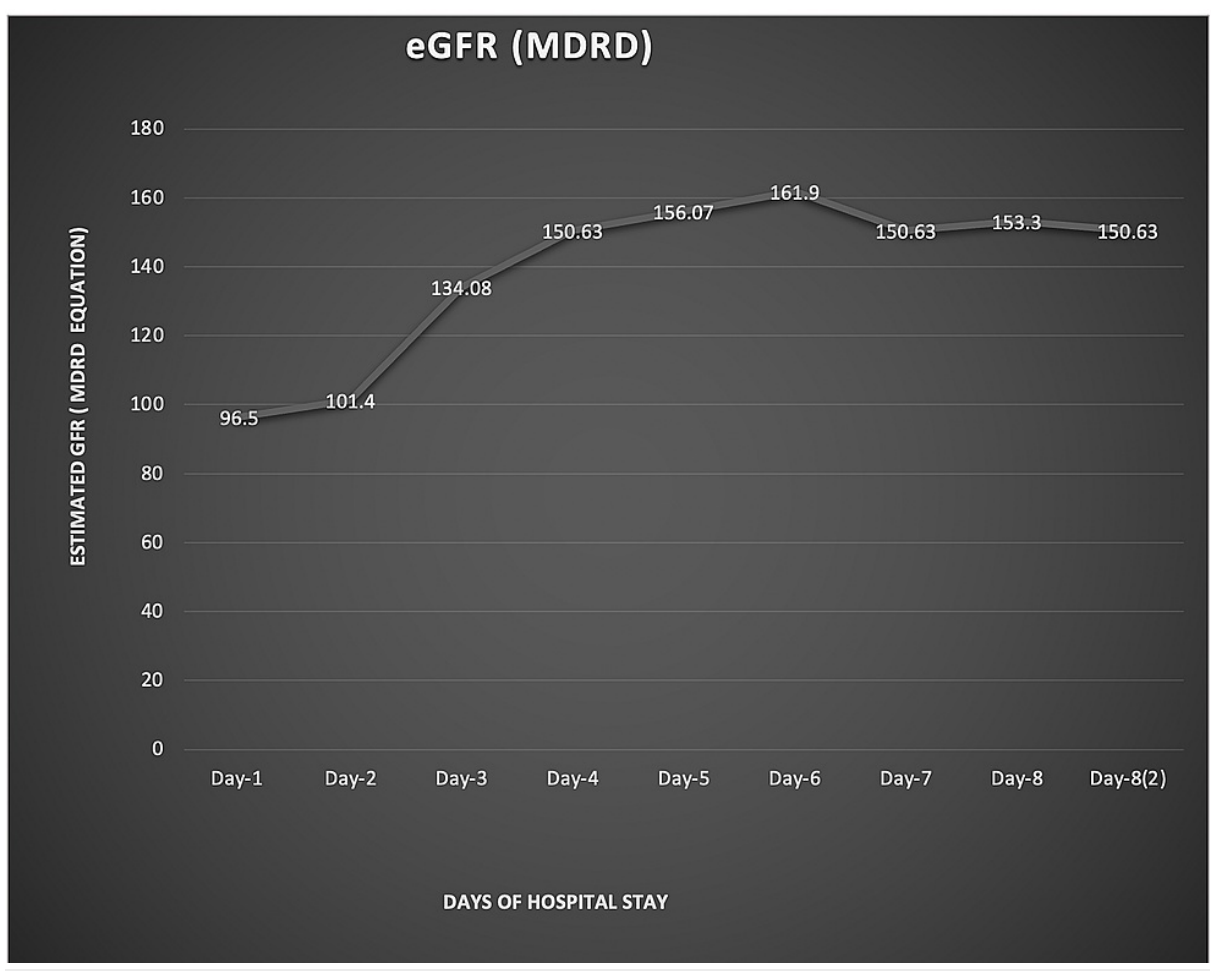

FIGURE 2: Estimated glomerular filtration rate (eGFR) trend based on the Modification of Diet in Renal Disease (MDRD) study equation

MDRD: Modification of Diet in Renal Disease; eGFR: estimated glomerular filtration rate

ARC was recorded on Day $3(134.08 \mathrm{ml} / \mathrm{min} / 1.73 \mathrm{~m} 2)$ and reached the highest value of $161.9 \mathrm{ml} / \mathrm{min} / 1.73$ $\mathrm{m}^{2}$ on Day 6. Despite the maximum recommended dose of vancomycin, there was a failure to achieve the therapeutic vancomycin level of $\sim 15-20 \mathrm{mg} / \mathrm{dl}$. Unfortunately, despite all efforts, the patient had worsening partial pressure of carbon dioxide/fraction of inspired oxygen $\left(\mathrm{PaCO}_{2} / \mathrm{FiO}_{2}\right)$ ratio with severe acute respiratory distress syndrome (ARDS), and the patient expired on the eighth day of hospital stay.

\section{Discussion}

The incidence of ARC ranges from $4.1 \%$ to $32.8 \%$ in studies done in intensive care settings [4,9]. Neurohormonal, temperature, vascular changes like cerebral autoregulation, fluid resuscitations, alteration of the physiology of nephrons, including but not limited to higher glomerular filtration, and variable tubular secretion and reabsorption have been suggested as the underlying pathophysiology of ARC [10-11]. Vancomycin being hydrophilic and excreted by up to $90 \%$ in urine in unchanged form, it is evident that vancomycin clearance depends on renal functioning and the phenomenon of ARC has a significant impact on [12].

Table 3 depicts recommended vancomycin interval dosing adjustment based on the eGFR level [7]. 


\section{Cureus}

\begin{tabular}{|l|l|}
\hline ARC stratification $\mathrm{CrCl}(\mathrm{mL} / \mathrm{min} / 1.73 \mathrm{~m} 2)$ & Recommended interval dosing of vancomycin \\
\hline Mild $130-150$ & $15-20 \mathrm{mg} / \mathrm{kg} \mathrm{q8}-12 \mathrm{hr}$ (up-to $4 \mathrm{gm} /$ day) \\
\hline Moderate $150-200$ & $3-4 \mathrm{~g} /$ day \\
High ARC $200-250$ & $4-4.5 \mathrm{~g} /$ day \\
Very high ARC $250-300$ & $4.5-5.5 \mathrm{~g} /$ day \\
extreme ARC $>300$ & $6.0 \mathrm{~g} /$ day \\
\hline
\end{tabular}

\section{TABLE 3: Recommended vancomycin as per ARC stratification}

Mahmoud SH, Shen C: Augmented Renal Clearance in Critical Illness: An Important Consideration in Drug Dosing. Pharmaceutics. 2017, 9:10.3390/pharmaceutics9030036 [7]

ARC: augmented renal clearance; eGFR: estimated glomerular filtration rate

Table 4 depicts the recommended daily vancomycin infusion dose adjustment based on eGFR [13].

\begin{tabular}{|ll|}
\hline Creatinine clearance $(\mathrm{ml} / \mathrm{min})$ & Vancomycin dosing $\mathbf{g m} / 24 \mathrm{hr}$ \\
\hline 30 & 1.1 \\
50 & 1.4 \\
75 & 1.9 \\
100 & 2.3 \\
125 & 2.7 \\
150 & 3.2 \\
175 & 3.6 \\
200 & 4.0 \\
225 & 4.5 \\
250 & 4.9 \\
275 & 5.3 \\
300 & 5.8 \\
325 & 6.7 \\
\hline
\end{tabular}

\section{TABLE 4: Recommended vancomycin infusion dose based on creatinine clearance}

Pea F, Furlanut M, Negri C, Pavan F, Crapis M, Cristini F, et al.: Prospectively validated dosing nomograms for maximizing the pharmacodynamics of vancomycin administered by continuous infusion in critically ill patients. Antimicrob Agents Chemother. 2009, 53:1863-7. 10.1128/AAC.01149-08 [13]

eGFR: estimated glomerular filtration rate

Many patients need dose adjustment due to the phenomenon of ARC, requiring extensive therapeutic drug monitoring (TDM) to ensure optimal therapy. In our case, vancomycin was started at $27.7 \mathrm{mg} / \mathrm{kg}$ and increased up-to $\sim 59 \mathrm{mg} / \mathrm{kg}$ on Days 5 and 6 . Despite these vancomycin doses, vancomycin levels were subtherapeutic, which led us to believe that the phenomenon of ARC is the reason for the therapeutic failure. Of note, vancomycin infusion therapy and therapeutic drug monitoring were successful strategies to achieve therapeutic vancomycin levels as observed by Udy et al., Lonsdale et al., and Goboova et al. in the setting of ARC [14-16].

Table 5 lists some case reports that report observations of ARC with vancomycin use. 


\section{Cureus}

\begin{tabular}{|c|c|c|c|c|c|c|}
\hline $\begin{array}{l}\text { Author/year } \\
\text { of } \\
\text { publication }\end{array}$ & $\begin{array}{l}\text { Age of } \\
\text { patient } \\
\text { (years) }\end{array}$ & Clinical settings & $\begin{array}{l}\text { Maximum eGFR } \\
\text { observed } \\
\left(\mathrm{ml} / \mathrm{min} / 1.73 \mathrm{~m}^{2}\right)\end{array}$ & $\begin{array}{l}\text { Maximum } \\
\text { vancomycin } \\
\text { dose used }\end{array}$ & $\begin{array}{l}\text { Strategies used to } \\
\text { overcome ARC }\end{array}$ & $\begin{array}{l}\text { Outcome after } \\
\text { intervention }\end{array}$ \\
\hline $\begin{array}{l}\text { Udy et al. } \\
\text { [14] (2010) }\end{array}$ & 41 & $\begin{array}{l}\text { Intra-abdominal } \\
\text { sepsis }\end{array}$ & 177 & $\begin{array}{l}4.5 \mathrm{~g} \text { over } 24 \\
\mathrm{~h}(49.45 \\
\mathrm{mg} / \mathrm{kg} / \text { day })\end{array}$ & Vancomycin infusion & $\begin{array}{l}\text { Achieved therapeutic } \\
\text { level and showed clinical } \\
\text { improvement }\end{array}$ \\
\hline $\begin{array}{l}\text { Lonsdale et } \\
\text { al. [15] } \\
(2013)\end{array}$ & 44 & $\begin{array}{l}\text { Subarachnoid } \\
\text { hemorrhage with } \\
\text { ventriculitis }\end{array}$ & 375 & $\begin{array}{l}6 \mathrm{~g} \text { over } 24 \mathrm{~h} \\
(63 \\
\mathrm{mg} / \mathrm{kg} / \text { day })\end{array}$ & Vancomycin infusion & $\begin{array}{l}\text { Achieved therapeutic } \\
\text { level and showed clinical } \\
\text { improvement }\end{array}$ \\
\hline $\begin{array}{l}\text { Goboova et } \\
\text { al. [16] } \\
(2015)\end{array}$ & 16 & $\begin{array}{l}\text { Sepsis, with } \\
\text { severe } \\
\text { polytrauma }\end{array}$ & 339.81 & $\begin{array}{l}6 \mathrm{~g} \text { over } 24 \mathrm{~h} \\
(67 \\
\mathrm{mg} / \mathrm{kg} / \text { day })\end{array}$ & $\begin{array}{l}\text { Therapeutic drug } \\
\text { monitoring and dose } \\
\text { adjustment }\end{array}$ & $\begin{array}{l}\text { Achieved therapeutic } \\
\text { level and showed clinical } \\
\text { improvement }\end{array}$ \\
\hline
\end{tabular}

TABLE 5: Observation of augmented renal clearance with vancomycin use in some case reports

ARC: augmented renal clearance; eGFR: estimated glomerular filtration rate

The previous recommendation endorsed $15-20 \mathrm{mg} / \mathrm{kg}$ of vancomycin for severe infection, including sepsis, while recent guidelines as per the American Association of Pharmacy and the Infectious Disease Society of America (IDSA) in 2020 recommend using $40 \mathrm{mg} / \mathrm{kg}$ initial loading dose and going up to $60 \mathrm{mg} / \mathrm{kg}$ of vancomycin for severe infection [17]. Chen et al. and Irriguible TM have recommended the alternate strategies of administering prolonged or continuous infusion or switching to an alternative antibiotic, which is not renally eliminated in the case of ARC [18-19]. Conventional dose adjustment of vancomycin based on eGFR may underestimate the clearance of vancomycin. Continuous infusion of vancomycin and measurement of the urine vancomycin clearance might provide better insight. However, measurement of urine vancomycin may not be available in all settings.

\section{Conclusions}

ARC is commonly associated with subtherapeutic vancomycin levels in critically ill patients. Early recognition of ARC is vital to reduce mortality. Despite the maximum recommended dose for severe infection like sepsis, ARC could lead to the therapeutic failure of vancomycin. Either measurement of vancomycin clearance or continuous infusion in liaison with the Infectious Disease or Pharmacy department could be a possible strategy for achieving the therapeutic level.

\section{Additional Information}

\section{Disclosures}

Human subjects: Consent was obtained or waived by all participants in this study. Conflicts of interest: In compliance with the ICMJE uniform disclosure form, all authors declare the following: Payment/services info: All authors have declared that no financial support was received from any organization for the submitted work. Financial relationships: All authors have declared that they have no financial relationships at present or within the previous three years with any organizations that might have an interest in the submitted work. Other relationships: All authors have declared that there are no other relationships or activities that could appear to have influenced the submitted work.

\section{References}

1. Hutschala D, Kinstner C, Skhirdladze K, Thalhammer F, Müller M, Tschernko E: Influence of vancomycin on renal function in critically ill patients after cardiac surgery: continuous versus intermittent infusion. Anesthesiology. 2009, 111:356-65. 10.1097/ALN.0b013e3181a97272

2. Vora S: Acute renal failure due to vancomycin toxicity in the setting of unmonitored vancomycin infusion . Proc (Bayl Univ Med Cent). 2016, 29:412-413. 10.1080/08998280.2016.11929491

3. Loirat P, Rohan J, Baillet A, Beaufils F, David R, Chapman A: Increased glomerular filtration rate in patients with major burns and its effect on the pharmacokinetics of tobramycin. N Engl J Med. 1978, 299:915-9. 10.1056/NEJM197810262991703

4. De Waele JJ, Dumoulin A, Janssen A, Hoste EA: Epidemiology of augmented renal clearance in mixed ICU patients. Minerva Anestesiol. 2015, 81:1079-85.

5. Baptista JP, Neves M, Rodrigues L, Teixeira L, Pinho J, Pimentel J: Accuracy of the estimation of glomerular filtration rate within a population of critically ill patients. J Nephrol. 2014, 27:403-10. 10.1007/s40620-0130036-x

6. Mulder MB, Eidelson SA, Sussman MS, et al.: Risk factors and clinical outcomes associated with augmented renal clearance in trauma patients. J Surg Res. 2019, 244:477-483. 10.1016/j.jss.2019.06.087 
7. Mahmoud SH, Shen C: Augmented renal clearance in critical illness: an important consideration in drug dosing. Pharmaceutics. 2017, 9:36. 10.3390/pharmaceutics9030036

8. Gerson SL, Kaplan SL, Bruss JB, Le V, Arellano FM, Hafkin B, Kuter DJ: Hematologic effects of linezolid: summary of clinical experience. Antimicrob Agents Chemother. 2002, 46:2723-6. 10.1128/AAC.46.8.27232726.2002

9. Nei AM, Kashani KB, Dierkhising R, Barreto EF: Predictors of augmented renal clearance in a heterogeneous ICU population as defined by creatinine and cystatin C. Nephron. 2020, 144:313-320. 10.1159/000507255

10. Dias C, Gaio AR, Monteiro E, et al.: Kidney-brain link in traumatic brain injury patients? A preliminary report. Neurocrit Care. 2015, 22:192-201. 10.1007/s12028-014-0045-1

11. Udy AA, Jarrett P, Lassig-Smith M, et al.: Augmented renal clearance in traumatic brain injury: a singlecenter observational study of atrial natriuretic peptide, cardiac output, and creatinine clearance. J Neurotrauma. 2017, 34:137-144. 10.1089/neu.2015.4328

12. Rybak MJ: The pharmacokinetic and pharmacodynamic properties of vancomycin. Clin Infect Dis. 2006, 42:S35-9. 10.1086/491712

13. Pea F, Furlanut M, Negri C, Pavan F, Crapis M, Cristini F, Viale P: Prospectively validated dosing nomograms for maximizing the pharmacodynamics of vancomycin administered by continuous infusion in critically ill patients. Antimicrob Agents Chemother. 2009, 53:1863-7. 10.1128/AAC.01149-08

14. Udy AA, Putt MT, Shanmugathasan S, Roberts JA, Lipman J: Augmented renal clearance in the intensive care unit: an illustrative case series. Int J Antimicrob Agents. 2010, 35:606-608. 10.1016/j.ijantimicag.2010.02.013

15. Lonsdale DO, Udy AA, Roberts JA, Lipman J: Antibacterial therapeutic drug monitoring in cerebrospinal fluid: difficulty in achieving adequate drug concentrations. J Neurosurg. 2013, 118:297-301. 10.3171/2012.10.JNS12883

16. Goboova M, Kuzelova M, Kissova V, Bodakova D, Martisova E: An adjustment of vancomycin dosing regimen for a young patient with augmented renal clearance: a case report. Eur Pharm J. 2015, 62:1-4.

17. Rybak MJ, Le J, Lodise TP, et al.: Therapeutic monitoring of vancomycin for serious methicillin-resistant Staphylococcus aureus infections: a revised consensus guideline and review by the American Society of Health-System Pharmacists, the Infectious Diseases Society of America, the Pediatric Infectious Diseases Society, and the Society of Infectious Diseases Pharmacists. Am J Health Syst Pharm. 2020, 77:835-864. 10.1093/ajhp/zxaa036

18. Chen IH, Nicolau DP: Augmented renal clearance and how to augment antibiotic dosing . Antibiotics. 2020, 9:393. 10.3390/antibiotics9070393

19. Irriguible TM: Augmented renal clearance: much more is better? Med Intensiva. 2018, 42:500-503. 10.1016/j.medin.2018.02.004 